IZA DP No. 4458

Do All Material Incentives for Prosocial Activities Backfire? The Response to Cash and Non-Cash Incentives for Blood Donations

Nicola Lacetera Mario Macis 


\title{
Do All Material Incentives for Prosocial Activities Backfire? The Response to Cash and Non-Cash Incentives for Blood Donations
}

\author{
Nicola Lacetera \\ Case Western Reserve University \\ Mario Macis \\ University of Michigan \\ and IZA \\ Discussion Paper No. 4458 \\ September 2009 \\ IZA \\ P.O. Box 7240 \\ 53072 Bonn \\ Germany \\ Phone: +49-228-3894-0 \\ Fax: +49-228-3894-180 \\ E-mail: iza@iza.org
}

Any opinions expressed here are those of the author(s) and not those of IZA. Research published in this series may include views on policy, but the institute itself takes no institutional policy positions.

The Institute for the Study of Labor (IZA) in Bonn is a local and virtual international research center and a place of communication between science, politics and business. IZA is an independent nonprofit organization supported by Deutsche Post Foundation. The center is associated with the University of Bonn and offers a stimulating research environment through its international network, workshops and conferences, data service, project support, research visits and doctoral program. IZA engages in (i) original and internationally competitive research in all fields of labor economics, (ii) development of policy concepts, and (iii) dissemination of research results and concepts to the interested public.

IZA Discussion Papers often represent preliminary work and are circulated to encourage discussion. Citation of such a paper should account for its provisional character. A revised version may be available directly from the author. 
IZA Discussion Paper No. 4458

September 2009

\section{ABSTRACT \\ Do All Material Incentives for Prosocial Activities Backfire? The Response to Cash and Non-Cash Incentives for Blood Donations}

Experimental studies document that financial rewards discourage the performance of altruistic activities, because they destroy intrinsic altruistic motivations. We set up a randomized-controlled experiment, through a survey administered to 467 blood donors in an Italian town, and find that donors are not reluctant to receive compensation in general: $A$ substantial share of respondents declared they would stop being donors if paid a small amount of cash, but we do not find such effects when a voucher of the same nominal value is offered instead. The aversion to direct cash payments is particularly marked among women and older respondents, while there are neither gender nor age differences in the response to the voucher. Implications for research and public policy are discussed.

JEL Classification: D12, D64, I18

Keywords: incentives, altruism, public good provision, pro-social behavior, public health

Corresponding author:

Mario Macis

Dept. of Business Economics and Public Policy

Ross School of Business, University of Michigan

701 Tappan St.

Ann Arbor, MI 48109-1234

USA

E-mail:mmacis@umich.edu 


\section{Introduction}

Blood transfusions are required in such critical situations as massive blood loss due to trauma, blood replacement during surgical interventions, and the treatment of premature babies, as well as to treat several chronic diseases including cancer. In recent years, the demand for blood has increased dramatically, due to, among other causes, an aging population and new medical and surgical procedures, such as organ transplants. In the western world, the supply of blood is a gratuitous, voluntary activity. However, even though many individuals are eligible to donate blood and numerous awareness campaigns are run to promote its importance, only a small percentage of eligible individuals (between 5\% and 10\%) donate blood in the western world and even fewer do so in developing countries. As a consequence, episodes of blood supply shortage (as defined by the supply of blood being below what is necessary for three days) are the norm rather than the exception (Di Rado 2004, Hemobiotech 2008, Oakley 1996).

Given these alarming shortages, "pure" altruism is apparently not enough to guarantee a steady supply of blood. Would additional, "material" incentives stimulate more donors to give their blood? Starting with Richard Titmuss' book The Gift Relationship (Titmuss 1971), the majority of scholars and policymakers have come to agree that the negative consequences of paid blood surpass the potential benefits. Titmuss' book was instrumental in advocating the end of a paid blood supply system in the US in the 1970s (Healy 2006). According to Titmuss' logic, explicitly paying for blood donations would not only attract people exclusively motivated by money, thus potentially reducing the quality of the blood collected, but could also reduce the altruism of donors who are intrinsically motivated, because the presence of a payment is in contrast with their beliefs or destroys the sense of "civic duty" associated with donating.

A number of experimental studies on the propensity of individuals to perform prosocial activities (not just blood donation) over the past thirty years confirm that offering material incentives "crowds out" the intrinsic motivation for these actions (Ariely et al. 2009, Bowles 2008, Deci 1975, Frey and Oberholzer-Gee 1997, Gneezy and Rustichini 2000). With specific reference to blood donations, surveys and experiments in New Zealand and Sweden show that donors are averse to the presence of financial rewards (Howden Chapman et al. 1996, Mellstrom and Johannesson 2008).

In most if not all of these studies, however, only one specific type of material reward is offered: cash. This raises the question of whether it is the type of material reward, rather than the presence of some explicit incentive in general, that makes potential contributors uncomfortable and less willing to perform an altruistic activity. There is, indeed, some evidence that people react to 
cash differently than to other forms of payment or reward with some cash value. For example, people are more likely to "steal" specific unattended items than unattended cash of the same value, and are more likely to report high level of performance in experiments, when they are paid with nonmonetary currency than when they are directly paid in cash (to be transformed in cash) (Mazar and Ariely 2006). A major psychological mechanism that seems to be at work in these cases is one of "self-concept maintenance." (Mazar et al. 2008). When stealing money directly, or cheating in order to receive plain cash, people have a hard time justifying (to themselves, first) their own action if not as dishonest. With other forms of payment, different motivations can be brought up and make one feel less guilty. A similar process might occur in the performance of prosocial activities such as blood donations. If paid directly with cash, the reward is more likely to be perceived as a direct compensation compared to other forms of reward. Specific items or coupons could be seen as an expression of gratitude and acknowledgment, to which intrinsically motivated individuals might show a positive attitude. Interestingly, while cash payments cannot be offered at Red Cross blood drives in the US, rewards in the form of specific items can instead be offered. In fact, with reference to blood donation in particular, some recent field studies have documented the positive impact of material incentives which are "steps removed" from direct cash, such as lottery tickets, in-kind or symbolic rewards, and the possibility of taking a paid day off work (Goette and Stutzer 2008, Lacetera and Macis (2008 a,b, Lacetera et al. 2009).

In this paper, we set up a randomized-controlled experiment, through a survey instrument administered to 467 Italian blood donors, to test the reaction of blood donors to different rewards of the same cash value: direct cash (10 euros), and a voucher for the purchase of some goods of the same nominal value. A strict observance of the "motivational crowding out" hypothesis would predict that donors are opposed to any form of payment. From a purely rational standpoint, instead, a payment in cash is never less preferable than an in-kind payment of the same dollar value. Finally, if donors are not averse to any form of payment, but have a specific aversion to direct cash payments, then we should observe a negative response to cash payments, but not to in-kind payments, for which the attitude can even be positive, e.g., leading donors to pledge to more frequent donations.

We find that although the majority of donors declare their donation behavior would not be affected by either cash or voucher payments, there is a large difference in the fraction of donors who declare they would stop donating between the "cash" and "voucher" groups. While only 3.5 percent responded they would stop donating if given a 10-euro voucher, about 13 percent declared they would stop being a donor if given 10 euros in cash. Thus, donors do not seem to display 
a general aversion to material incentives, but a substantial fraction shows a marked aversion to cash payments. We also explore whether the relative aversion to cash payments is correlated with observable donor characteristics. Of particular interest is the issue of gender differences. Research from a number of fields suggests that gender differences exist, for example, in attitudes toward competition, cooperation, and risk taking, and attempts have been made to separate the biological and environmental determinants of these differences (see Croson and Gneezy 2009 for a survey). The recent experiment in Sweden by Mellstrom and Johannesson (2008) mentioned above found that women are more reluctant to become blood donors if money is offered to them. Interestingly, in our study we also find large gender differences. In fact, female donors display a stronger aversion to cash payments when compared to males, with about 21 percent of female donors declaring they would reduce or stop donating if offered cash, against about 11 percent of males. Older donors, too, show a stronger aversion to cash payments, with percentages above 30 percent among older females. Finally, when asked general questions about attitudes toward donations, donors reveal a high degree of consistency between different "extrinsic" reasons for donating: Donors who are not reluctant to receive a reward for their donation also see explicit payments to donors in general with high favor, and would not oppose measures which would publicly recognize donation activities.

The remainder of this paper is organized as follows. In Section 2, we describe the institutional background, the experimental design, the participants, and the resulting data. In Section 3, we present our findings. In Section 4 we conclude and discuss the implications of our work for policies aimed at increasing blood donations and charitable contributions in general.

\section{Institutional background and Data}

\subsection{Blood donation in Italy and in The Town}

The data used in this study originate from a questionnaire distributed to all donors in an Italian town ("The Town" hereinafter) ${ }^{1}$ located in the Center-North part of the country. Before describing the data and our methods, we report on the blood donation system in Italy and in The Town. Blood donation in Italy is organized through blood banks, which are run by voluntary donor associations.

\footnotetext{
${ }^{1}$ In order to protect the privacy of the donors in our database, we have agreed to keep the name of The Town (as well as any other identifying information) confidential. The demographic, social, and economic characteristics of The Town's population are highly representative of the overall Italian urban population. Statistics comparing the Town with other Italian towns under a number of socio-economic characteristics are available upon request. We are extremely thankful to the President, Board, members, and staff of The Town's unit of the Italian Association of Blood Donors (Associazione Volontari Italiani del Sangue, AVIS), to the Head and staff of the Transfusion Unit in The Town's Hospital, and to Raffaella Manna, for their precious collaboration.
} 
These associations have a central headquarters as well as town-level units. In order to donate blood, an individual is required to become a member of one of these associations. The three major associations, which are present in different parts of the country and do not compete with one another, are Associazione Volontari Italiani del Sangue (AVIS), with about 1.1 million members in 2007, Federazione Italiana delle Associazioni Donatori di Sangue (FIDAS), with about 400,000 members (Caligaris 2007), and Fratres (150,000 members in 2000). ${ }^{2}$ Since the affiliation is to a local unit of the national associations, blood donors predominantly donate in the town where "their" unit is located. In The Town, blood donation is managed by the largest blood donor association, AVIS, and aphereses of either whole blood or blood's components (plasma, platelets) are performed at The Town's public hospital, Monday through Saturday from 8 to 11 a.m. The waiting time for a donation varies, and is typically comprised between ten minutes and thirty minutes. Part of the wait is due to the requirement of donors to fill in and sign a consent form regarding their health status. The donation of blood and blood components is entirely gratuitous, since neither cash nor promotion items can be given to donors. ${ }^{3}$

\subsection{Data, Participants and Survey Design}

A survey was constructed in collaboration with the local AVIS office, and was proposed to all donors presenting between August 1, 2007 and October 31, 2007. The questionnaire was administered by the personnel of the Transfusion Unit, who also handled the informed consent forms. The survey was completely anonymous and participation was voluntary.

The survey was presented by AVIS as a way for their local chapter to better understand their donors' behaviors and attitudes regarding blood donation. A first set of questions concerned demographic and general attitudes and characteristics, such as age range, education level, gender, education, and religiosity. A second set of questions concerned donation habits, such as the frequency of yearly donations, or whether the respondent used to come to donate with others and had other donors in his/her family. A further set of questions asked how the respondents came to know about the AVIS activity, and a final set of questions elicited donors' opinions on what AVIS can do

\footnotetext{
${ }^{2}$ Blood donations run through blood banks and voluntary donor associations (which were present since the 1920s) have become the official blood donation and collection system in Italy, after a brief period, following the end of World War II, when the Red Cross played a prominent role. Similar blood bank systems exist in other countries, such as Denmark, Greece, Norway, Portugal, and Spain. In the UK, France, and Ireland, by contrast, the organization of blood donation is run by the State. The Red Cross, finally, is the dominant organization managing blood donation in such countries as Belgium, The Netherlands, Germany, and the US. In the US, however, the system is more heterogeneous and competitive, comprising the Red Cross, blood banks, and hospitals directly managing blood donations.

${ }^{3}$ Donors who are employee have the right to a one-day leave of absence on the day they donate (Lacetera and Macis 2008a.
} 
to increase donors and donations. All questions were multiple choice. A copy of the questionnaire is available from the Authors upon request. The survey took between five and ten minutes to be completed. Given the standard waiting time reported above, responding to the survey did not add any major inconvenience to the donors.

Within this survey structure, we had authorization to add one question regarding attitudes toward the presence of material incentives to reward blood donors. Specifically, the respondents were randomly assigned to one of two versions of the added question. One version asked: "If each donor was given 10 euros at each donation, you would donate..."; the other version asked: "If each donor was given a 10-euro voucher to purchase books or food at each donation, you would donate...", and the same set of (mutually exclusive) answers was provided: 1. I would donate less often than I currently do; 2. I would donate as often as I currently do; 3. I would donate more often than I currently do; 4. I would no longer want to be a blood donor. The use of a hypothetical question is an application of the "vignette" technique used frequently in sociological research and, more recently, also in behavioral economics studies (Neckerman and Frey 2007, Opp 2002, Rossi and Nock 1982). Through this research design, our objective was to assess whether cash-equivalent rewards generate the same behavioral response (or at least the same reaction), or instead, whether the type of reward, holding its value constant, affects the responses. The assignment to one of the two treatments was random, and neither the respondent nor the personnel proposing and distributing the survey were informed or aware of the presence of the two treatments.

A total of 490 donors answered our questionnaires, giving a response rate between 55 and 65 percent. ${ }^{4}$ We discarded 23 questionnaires, which were missing most of the information, thus we were left with 467 respondents with valid answers. Descriptive statistics are provided in Table 1. The median respondent is a male, age 40-49 and with a high school diploma, and has been a donor for at least 4 years. Table 1 confirms that the donors' observable characteristics - gender, age, and seniority as donors - do not differ substantially between treatment groups; also, the sample appears to be very representative of the whole population of donors in The Town. ${ }^{5}$

[Table 1 about here]

\footnotetext{
${ }^{4}$ To preserve the anonymity of The Town we cannot reveal the exact number of donors presenting in the period of interest, therefore we cannot report the exact response rate and also provide a range.

${ }^{5}$ The AVIS chapter of The Town kindly provided the data for the last column of Table 1.
} 


\section{Findings}

Figure 1 reports the distribution of the answers to the key question "If each donor was given $\mathrm{X}$ at each donation, you would donate...," by the type of reward X, i.e., 10 euros cash or a 10-euro voucher to be used for books or food. Even though in both cases the vast majority of donors declare their donation behavior would not be affected, there is a striking difference in the fraction of donors who declare they would stop donating between the "cash" and "voucher" groups. Among those who were assigned a questionnaire with the "voucher" question, only 3.5 percent responded they would stop being blood donors, against 12.9 percent of those who were assigned the "cash" version of that question (the difference is statistically significant at the $1 \%$ level).

[Figure 1 about here]

In Figures 2 and 3, we investigate whether observable donor characteristics are systematically correlated with the differential response to the cash and the voucher reward.

[Figure 2 about here]

[Figure 3 about here]

Figure 2 reports the fraction of respondents who answered that they would donate less or stop being donors if cash/voucher was offered, separately by gender. The fraction of donors who would donate less or stop donating in response to a cash incentive is higher than that in response to a voucher of the same nominal value, for both genders. The differences are significant at the $5 \%$ level for males and at the $1 \%$ level for females. However, a marked gender difference emerges in the response to the "cash" incentive, with $20.8 \%$ of female donors declaring they would reduce or stop donating if offered cash, against $10.9 \%$ of males. This gender difference is statistically significant at the $5 \%$ level.

Figure 3 documents the extent to which attitudes toward material incentives to blood donation differ by age, and the differential effect of cash vs. voucher. The age gradient in the cash-voucher difference is very pronounced, with a larger fraction of older donors declaring they would stop donating if offered cash. Once again, the percentages and the differences are particularly marked among female donors, and in spite of the relatively small sample size, many of the differences are statistically significant at the conventional levels. Table 2 reports the numerical values behind figures 1,2 , and 3 .

[Table 2 about here] 
The regression analyses reported in Table 4 corroborate further the findings just described. The dependent variable is equal to 1 if a donor responded "I would stop donating" or "I would donate less" to the treatment questions, and 0 otherwise. We report the estimated coefficients on a series of independent variables indicating gender, age groups, "seniority" as donors, education, and religious attitudes. The estimates are from a simple linear probability model. Binary specifications such as probit and logit convey very similar results (available from the Authors upon request). The results are also divided by treatment and, for the cash treatment, also by gender of the respondents. The findings confirm a significantly greater aversion of female donors, especially of older age, to cash payments. On the other hand, donors with higher educational attainment, especially males with at least a college degree, seem to be less reluctant toward receiving cash payments. No other donor characteristics in the regressions appear to be systematically correlated with the reactions to payments (of different types) for donation. Interestingly, we do not detect any significant differences across donors with different religious attitudes.

\section{[Table 3 about here]}

In Table 4, we consider the average and median rates given by respondents to some sentences in the survey. The donors were asked to give these sentences a rate from 1 ("strongly disagree") to 5 ("strongly agree"). ${ }^{6}$ Therefore, a higher mean or median grade indicates higher agreement with the sentence. The four sentences reported in Table 3 were meant to capture different motivations and attitudes of donors toward donation: a "feeling good" motivation ("Donating blood makes me feel a better person"); a "purely selfish" attitude (as captured by the sentence: "Blood donors should have priority over non donors if they need a transfusion"); and a "social image" motive (as from the sentence: "The names of the donors should be made public"). Finally, and also as a way to test the consistency with the answers to the treatment question on the hypothetical reward, a fourth sentence read: "Paying blood donors would stimulate more donations." The average and median rates are broken down by the treatment question to which the respondents were assigned (voucher versus cash), and, within treatment, respondents are divided between those who responded to the treatment questions that they would stop donating or that they would donate less, and those who would not change their donation frequency or would increase donations. The results are interesting in that they reveal consistency between different "extrinsic motives." Those who are not reluctant to receive a reward see payments to donors more in general with higher favor, and also agree more on donors' names being publicly known. By contrast, there is no difference in "intrinsic motives"

\footnotetext{
${ }^{6}$ The respondents also had a sixth option, "Don’t know."
} 
among different treatments and responses: All subgroups give similar rates to the "feeling good" sentence. Note also that the average and median values for this sentence are significantly higher than those given to any other sentence, thus revealing that intrinsic motives are dominant, as expected. Finally, no differences emerge on the "priority-to-donors" sentence: Respondents do not differ in terms of this "selfish" motive. This absence of differences is not inconsistent with the differences found on the payment sentence because, here, we are looking at a different form of extrinsic motive, not related to getting "paid for performance." Moreover, the relatively low ratings on the "priority-to-donors" sentence reveal also that, regardless of whether the motivations are intrinsic or extrinsic, and regardless of the differences in the motivation, the underlying driver of the decision to donate is some form of altruism, i.e., people donate to benefit others and not themselves.

[Table 4 about here]

\section{Interpretation and Implications}

The findings of this study are consistent with the hypothesis that donors are not averse to any form of reward for their prosocial actions, but, specifically, they are reluctant to being paid cash. It is, therefore, the idea of being directly or explicitly paid (with cash) for an altruistic act, and not the sense of being rewarded (e.g., with a voucher) that appears to be particularly disturbing to donors.

Our results are consistent with the evidence of "crowding out" found in most experimental studies of incentives for prosocial behavior. However, it appears that the greater aversion to payment documented for women and older donors is specific to cash payments rather than being due to the presence of any form of material reward per se.

In light of these findings, such policies as the prohibition by the American Red Cross to pay blood donors directly with cash would appear appropriate. More generally, an insight of this study for charitable organizations and policymakers interested in stimulating pro-social behavior concerns the understanding of the motives for performing such activities. We find that a feeling of gratitude and acknowledgement is rewarding for donors. Therefore, stimulating these feelings, possibly also through material incentives as long as they are "steps removed" from rewards too immediately identified as a form of direct "pay for performance" (such as cash), might not collide with the intrinsic motivations of donors, and could potentially contribute to alleviate supply shortages of such socially relevant activities as blood donation. 


\section{References}

[1] Ariely, D., Bracha, A. and Meier, S., 2009: "Doing Good or Doing Well? Image Motivation and Monetary Incentives in Behaving Prosocially," American Economic Review, 99, 1, 544-555.

[2] Bowles, S., 2008: "Policies Designed for Self-Interested Citizens May Undermine "The Moral Sentiments": Evidence from Economic Experiments," Science, 320, 5883, 1605-09.

[3] Caligaris, A.O., 2007: "Relazione del Presidente," 46th National Annual Conference, FIDAS.

[4] Croson, R. and Gneezy, U., 2009: "Gender Differences in Preferences," Journal of Economic Literature, $47,2,448-74$.

[5] Deci, E.L., 1975: Intrinsic Motivation, Plenum Press.

[6] Di Rado, A., 2004: "All You Need Is Blood," USC Health Magazine, Fall issue.

[7] Frey, B.S. and Oberholzer-Gee, F., 1997: "The Cost of Price Incentives: An Empirical Analysis of Motivation Crowding-Out," American Economic Review, 87, 4, 746-755.

[8] Gneezy, U., and Rustichini,A., 2000: "Pay Enough or Don't Pay At All," Quarterly Journal of Economics, August, 791-810.

[9] Goette, L., and Stutzer, A., 2008: "Blood Donation and Incentives: Evidence from a Field Experiment," IZA Working Paper 3580.

[10] Healy, K., 2006: Last Best Gifts. Altruism and the Market for Human Blood and Organs, University Of Chicago Press.

[11] Hemobiotech, 2008: http://www.hemobiotech.com.

[12] Howden Chapman, P., Carter, J. and Woods, N., 1996: "Blood Money: Blood Donors' Attitudes to Changes in the New Zealand Blood Transfusion Service," British Medical Journal, 312, 1131-32.

[13] Lacetera, N. and Macis, M., 2008a: "Motivating Altruism: A Field Study," IZA working paper 3770.

[14] Lacetera, N. and Macis, M., 2008b: "Social Image Concerns and Pro-Social Behavior," IZA working paper 3771 .

[15] Lacetera, N., Macis, M. and Slonim, R., 2009: "Increasing Donations or Stealing Altruism? Material Incentives and Substitution Effects in Pro-Social Behavior," working paper. 
[16] Mazar, N. and Ariely, D., 2006: "Dishonesty in Everyday Life and its Policy Implications," Journal of Public Policy and Marketing, 25, 1, 117-26.

[17] Mazar, N., On, A. Ariely, D., 2008: "The Dishonesty of Honest People: A Theory of Self-Concept Maintenance", Journal of Marketing Research, 45, 6, 633-44.

[18] Mellstrom, C. and Johannesson, M., 2008: "Crowding Out in Blood Donation: Was Titmuss Right?," Journal of the European Economic Association, 6, 4, 845-63.

[19] Neckermann, S., and Frey, B.S., 2007: "Awards as Incentives," Institute for Empirical Research in Economics Working Paper No. 334.

[20] Oakley, A., 1996: "Blood Donation - Altruism or Profit?," British Medical Journal, 312, 1114.

[21] Opp, K.-D., 2002: "When Do Norms Emerge by Human Design and When by the Unintended Consequences of Human Action?," Rationality and Society, 14, 131-58.

[22] Rossi, P. and Nock, S. (eds), 1982: Measuring Social Judgments: The Factorial Survey Approach, Sage.

[23] Titmuss, R.M., 1971: The Gift Relationship, London: Allen and Unwin. 


\section{A Tables and Figures}

\begin{tabular}{|c|c|c|c|c|c|c|c|}
\hline \multirow{3}{*}{ Variable } & & & \multicolumn{4}{|c|}{ Treatment } & \multirow{3}{*}{$\begin{array}{l}\text { All donors in } \\
\text { The Town }\end{array}$} \\
\hline & \multicolumn{2}{|c|}{$\begin{array}{l}\text { Entire } \\
\text { Sample }\end{array}$} & \multicolumn{2}{|c|}{ Voucher } & \multicolumn{2}{|l|}{ Cash } & \\
\hline & $\%$ & $\mathrm{~N}$ & $\%$ & $\mathrm{~N}$ & $\%$ & $\mathrm{~N}$ & \\
\hline $\begin{array}{l}\text { Treatment } \\
\text { cash } \\
\text { voucher }\end{array}$ & $\begin{array}{l}44.97 \\
55.03\end{array}$ & $\begin{array}{l}210 \\
257\end{array}$ & & & & & \\
\hline $\begin{array}{l}\text { Female } \\
\text { Male }\end{array}$ & $\begin{array}{l}26.1 \\
73.9\end{array}$ & $\begin{array}{l}119 \\
337\end{array}$ & $\begin{array}{l}28.17 \\
71.83\end{array}$ & $\begin{array}{l}71 \\
181\end{array}$ & $\begin{array}{l}23.53 \\
76.47\end{array}$ & $\begin{array}{l}48 \\
156\end{array}$ & $\begin{array}{l}30.8 \\
69.2\end{array}$ \\
\hline $\begin{array}{l}\text { Age } \\
18-29 \\
30-39 \\
40-49 \\
50-65\end{array}$ & $\begin{array}{c}15.54 \\
27.79 \\
34.57 \\
22.1\end{array}$ & $\begin{array}{l}71 \\
127 \\
158 \\
101\end{array}$ & $\begin{array}{c}17.79 \\
25.3 \\
35.97 \\
20.95\end{array}$ & $\begin{array}{l}45 \\
64 \\
91 \\
53\end{array}$ & $\begin{array}{l}12.75 \\
30.88 \\
32.84 \\
23.53\end{array}$ & $\begin{array}{l}26 \\
63 \\
67 \\
48\end{array}$ & $\begin{array}{l}15.96 \\
32.29 \\
30.79 \\
20.96\end{array}$ \\
\hline $\begin{array}{l}\text { Donor Since } \\
\text { less than } 1 \text { year } \\
1-2 \text { years } \\
2-4 \text { years } \\
4-10 \text { years } \\
\text { over } 10 \text { years }\end{array}$ & $\begin{array}{c}12.64 \\
9.15 \\
13.94 \\
25.71 \\
38.56\end{array}$ & $\begin{array}{l}58 \\
42 \\
64 \\
118 \\
177\end{array}$ & $\begin{array}{l}11.55 \\
11.16 \\
15.94 \\
21.91 \\
39.44\end{array}$ & $\begin{array}{l}29 \\
28 \\
40 \\
55 \\
99\end{array}$ & $\begin{array}{c}13.94 \\
6.73 \\
11.54 \\
30.29 \\
37.5\end{array}$ & $\begin{array}{l}29 \\
14 \\
24 \\
63 \\
78\end{array}$ & \begin{tabular}{c|c}
13.69 \\
8.46 \\
13.43 \\
30.24 \\
34.19
\end{tabular} \\
\hline $\begin{array}{l}\text { Education } \\
\text { less than high school } \\
\text { high school } \\
\text { college or higher }\end{array}$ & $\begin{array}{c}23.8 \\
54.15 \\
22.05\end{array}$ & $\begin{array}{l}109 \\
248 \\
101\end{array}$ & $\begin{array}{l}25.30 \\
55.73 \\
18.97\end{array}$ & $\begin{array}{l}64 \\
141 \\
48\end{array}$ & $\begin{array}{l}21.95 \\
52.20 \\
25.85\end{array}$ & $\begin{array}{l}45 \\
107 \\
53\end{array}$ & $\begin{array}{l}\text { na } \\
\text { na } \\
\text { na }\end{array}$ \\
\hline $\begin{array}{l}\text { Religion } \\
\text { atheist/agnostic } \\
\text { catholic, observant } \\
\text { catholic, non-observant } \\
\text { non-catholic }\end{array}$ & $\begin{array}{c}10.96 \\
32.89 \\
55.26 \\
0.88\end{array}$ & $\begin{array}{l}50 \\
150 \\
252 \\
4\end{array}$ & $\begin{array}{c}11.11 \\
36.11 \\
51.19 \\
1.59\end{array}$ & $\begin{array}{l}28 \\
91 \\
129 \\
4\end{array}$ & $\begin{array}{c}10.78 \\
28.92 \\
60.29 \\
0.00\end{array}$ & $\begin{array}{l}22 \\
59 \\
123 \\
0\end{array}$ & $\begin{array}{l}\text { na } \\
\text { na } \\
\text { na } \\
\text { na }\end{array}$ \\
\hline
\end{tabular}

Table 1: Descriptive Statistics of the sample population and the universe of blood donors in The Town. Data are reported as both percentages and numbers of valid answers. Answers to some of the questions were sometimes missing. The demographic information on the respondents comes from the answers to the survey. The AVIS chapter of The Town kindly provided the information on the whole population of donors in year 2007 (data are reported only in percentage terms for confidentiality reasons). 


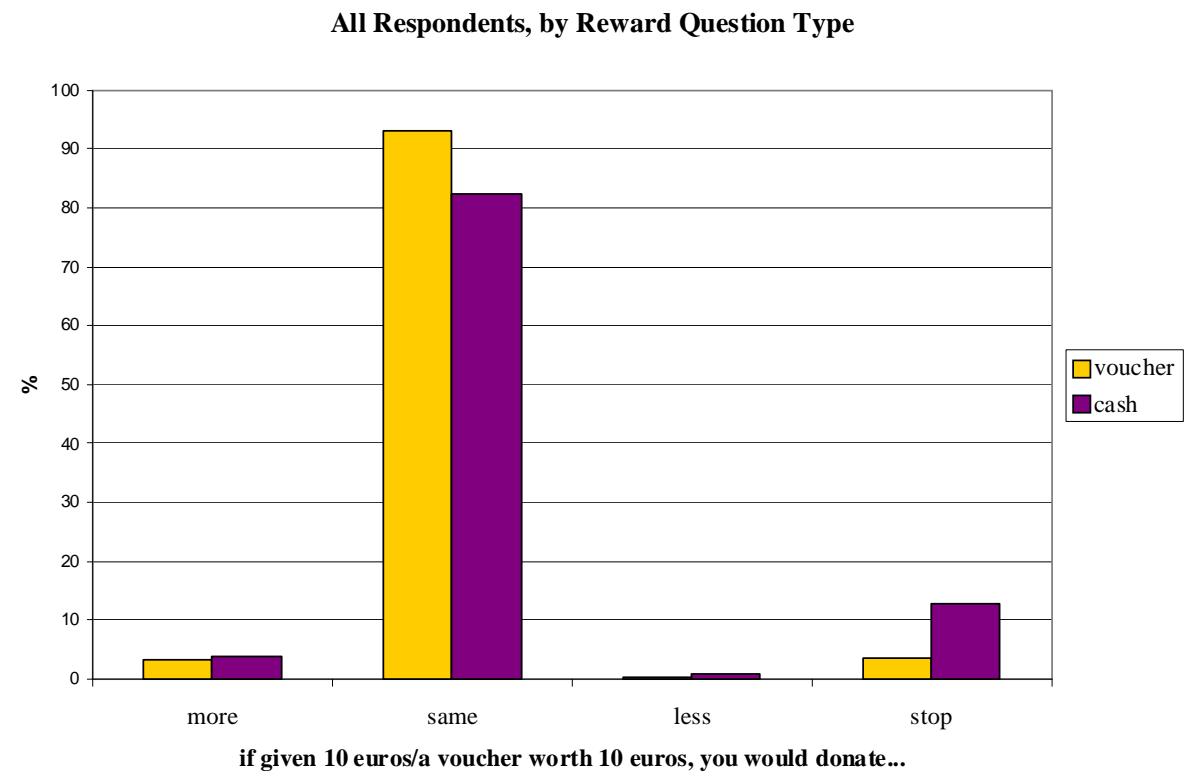

Figure 1: Distribution of responses to the "hypothetical payment" question, by type of payment. 
All respondents, by "voucher/cash" question and gender

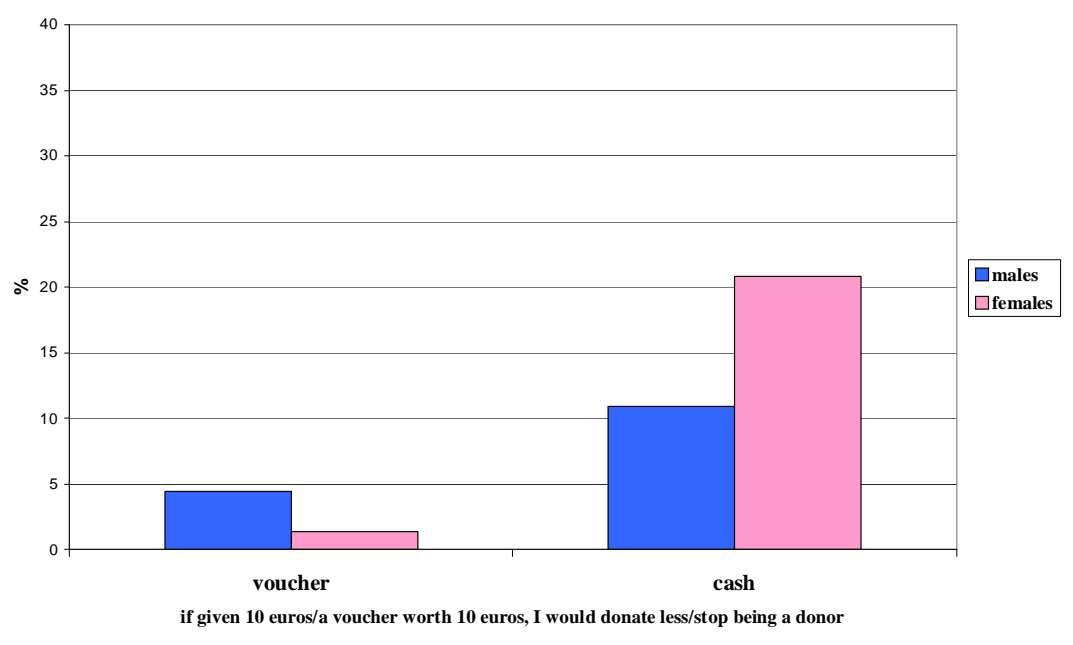

Figure 2: Percentage of males and females responding they would stop being donors or would donate less often, by type of payment.

All respondents, by "voucher/cash" question, gender and age

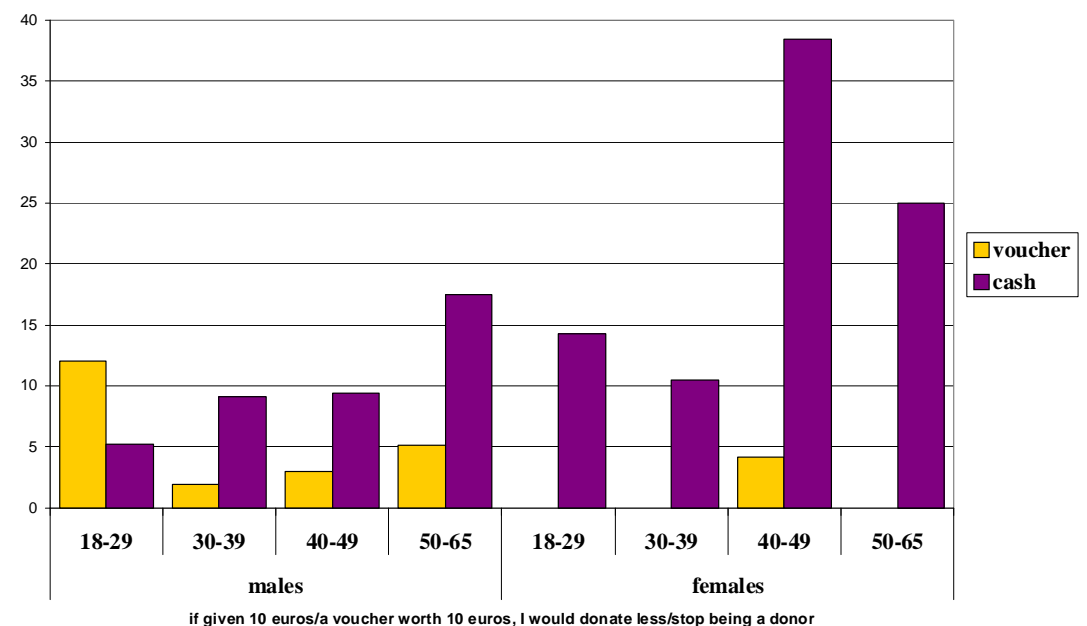

Figure 3: Percentage of donors responding they would stop being donors or would donate less often, by type of payment, age group and gender. 


\begin{tabular}{|c|c|c|c|c|c|c|c|c|c|c|}
\hline & & & & & anel A & & & & & \\
\hline If given 10 eu & uche & worth 10 & os, you & uld don & & & & & & \\
\hline & & & esponde & & & males & & & females & \\
\hline & & trea & & & trea & & & trea & & \\
\hline & & voucher & cash & total & voucher & cash & total & voucher & cash & total \\
\hline more often & $\mathrm{n}$ & 8 & 8 & 16 & 7 & 4 & 11 & 1 & 4 & 5 \\
\hline & $\%$ & 3.11 & 3.81 & 3.43 & 3.87 & 2.56 & 3.26 & 1.41 & 8.33 & 4.2 \\
\hline same as now & $\mathrm{n}$ & 239 & 173 & 412 & 166 & 135 & 301 & 69 & 34 & 103 \\
\hline & $\%$ & 93.00 & 82.38 & 88.22 & 91.71 & 86.54 & 89.32 & 97.18 & 70.83 & 86.55 \\
\hline less often & $\mathrm{n}$ & 1 & 2 & 3 & 1 & 2 & 3 & 0 & 0 & 0 \\
\hline & $\%$ & 0.39 & 0.95 & 0.64 & 0.55 & 1.28 & 0.89 & 0.00 & 0.00 & 0.00 \\
\hline I would stop & $\mathrm{n}$ & 9 & 27 & 36 & 7 & 15 & 22 & 1 & 10 & 11 \\
\hline donating & $\%$ & 3.50 & 12.86 & 7.71 & 3.87 & 9.62 & 6.53 & 1.41 & 20.83 & 9.24 \\
\hline total & $\mathrm{n}$ & 257 & 210 & 467 & 181 & 156 & 337 & 71 & 48 & 119 \\
\hline & $\%$ & 100 & 100 & 100 & 100 & 100 & 100 & 100 & 100 & 100 \\
\hline & & & & & anel B & & & & & \\
\hline
\end{tabular}

If given 10 euros/a voucher worth 10 euros, you would donate...

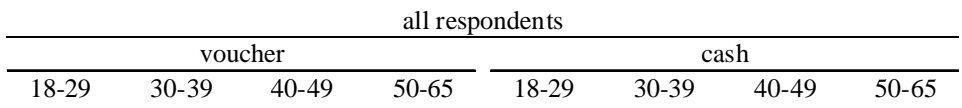

\begin{tabular}{lccccccccc} 
more often & $\mathrm{n}$ & 3 & 2 & 3 & 0 & 0 & 3 & 4 & 0 \\
& $\%$ & 6.67 & 3.13 & 3.3 & 0 & 0 & 4.76 & 5.97 & 0 \\
same as now & $\mathrm{n}$ & 39 & 61 & 85 & 51 & 24 & 54 & 53 & 39 \\
& $\%$ & 86.67 & 95.31 & 93.41 & 96.23 & 92.31 & 85.71 & 79.1 & 81.25 \\
\multirow{2}{*}{ less often } & $\mathrm{n}$ & 1 & 0 & 0 & 0 & 0 & 1 & 0 & 1 \\
& $\%$ & 2.22 & 0 & 0 & 0 & 0 & 1.59 & 0 & 2.08 \\
& & & & & & & & & \\
I would stop & $\mathrm{n}$ & 2 & 1 & 3 & 2 & 2 & 5 & 10 & 8 \\
donating & $\%$ & 4.44 & 1.56 & 3.3 & 3.77 & 7.69 & 7.94 & 14.93 & 16.67 \\
total & $\mathrm{n}$ & 45 & 64 & 91 & 53 & 26 & 63 & 67 & 48 \\
& $\%$ & 100 & 100 & 100 & 100 & 100 & 100 & 100 & 100
\end{tabular}

Table 2: Numerical values behind the figures reported in the main text, regarding the reactions to the treatment questions on hypothetical rewards for donations. The data are reported in absolute and percentage terms. 


\begin{tabular}{|c|c|c|c|c|c|c|c|c|c|c|c|c|}
\hline & \multicolumn{12}{|c|}{$\begin{array}{c}\text { Dependent Variable = } 1 \text { if individual would donate less or stop if given voucher/cash } \\
\text { Treatment }\end{array}$} \\
\hline & \multicolumn{3}{|c|}{ Voucher } & \multicolumn{3}{|c|}{ Cash } & \multicolumn{6}{|c|}{ Cash } \\
\hline & & & & & & & & Males & & & Females & \\
\hline & (1) & (2) & (3) & (4) & (5) & (6) & (7) & (8) & (9) & (10) & (11) & (12) \\
\hline female & $\begin{array}{l}-0.030 \\
(0.026)\end{array}$ & $\begin{array}{l}-0.038 \\
(0.027)\end{array}$ & $\begin{array}{l}-0.034 \\
(0.027)\end{array}$ & $\begin{array}{c}0.117^{* *} \\
(0.056)\end{array}$ & $\begin{array}{l}0.113 * \\
(0.058)\end{array}$ & $\begin{array}{c}0.141^{* *} \\
(0.060)\end{array}$ & & & & & & \\
\hline age $40-65$ & $\begin{array}{l}-0.003 \\
(0.024)\end{array}$ & $\begin{array}{l}0.007 \\
(0.025)\end{array}$ & $\begin{array}{c}0.002 \\
(0.026)\end{array}$ & $\begin{array}{c}0.0894^{*} \\
(0.048)\end{array}$ & $\begin{array}{c}0.105^{* *} \\
(0.051)\end{array}$ & $\begin{array}{c}0.0990^{*} \\
(0.052)\end{array}$ & $\begin{array}{c}0.050 \\
(0.051)\end{array}$ & $\begin{array}{c}0.051 \\
(0.055)\end{array}$ & $\begin{array}{c}0.036 \\
(0.056)\end{array}$ & $\begin{array}{l}0.218^{*} \\
(0.120)\end{array}$ & $\begin{array}{c}0.290^{* *} \\
(0.130)\end{array}$ & $\begin{array}{c}0.329 * * \\
(0.160)\end{array}$ \\
\hline \multicolumn{13}{|l|}{ donor since } \\
\hline 2-4 years & & $\begin{array}{l}-0.004 \\
(0.039)\end{array}$ & $\begin{array}{l}-0.008 \\
(0.039)\end{array}$ & & $\begin{array}{l}-0.022 \\
(0.090)\end{array}$ & $\begin{array}{l}-0.023 \\
(0.093)\end{array}$ & & $\begin{array}{l}-0.016 \\
(0.100)\end{array}$ & $\begin{array}{l}-0.014 \\
(0.100)\end{array}$ & & $\begin{array}{l}-0.047 \\
(0.190)\end{array}$ & $\begin{array}{l}-0.055 \\
(0.220)\end{array}$ \\
\hline $4-10$ years & & $\begin{array}{l}-0.022 \\
(0.036)\end{array}$ & $\begin{array}{l}-0.032 \\
(0.037)\end{array}$ & & $\begin{array}{c}-0.008 \\
(0.070)\end{array}$ & $\begin{array}{l}-0.007 \\
(0.071)\end{array}$ & & $\begin{array}{c}0.049 \\
(0.076)\end{array}$ & $\begin{array}{c}0.051 \\
(0.077)\end{array}$ & & $\begin{array}{l}-0.211 \\
(0.170)\end{array}$ & $\begin{array}{l}-0.266 \\
(0.200)\end{array}$ \\
\hline \multicolumn{2}{|c|}{ more than 10 years } & $\begin{array}{l}-0.042 \\
(0.033)\end{array}$ & $\begin{array}{l}-0.045 \\
(0.033)\end{array}$ & & $\begin{array}{l}-0.056 \\
(0.070)\end{array}$ & $\begin{array}{l}-0.056 \\
(0.072)\end{array}$ & & $\begin{array}{c}0.013 \\
(0.078)\end{array}$ & $\begin{array}{c}0.029 \\
(0.078)\end{array}$ & & $\begin{array}{l}-0.232 \\
(0.160)\end{array}$ & $\begin{array}{l}-0.310 \\
(0.190)\end{array}$ \\
\hline high school & & & $\begin{array}{l}-0.041 \\
(0.030)\end{array}$ & & & $\begin{array}{l}-0.028 \\
(0.063)\end{array}$ & & & $\begin{array}{l}-0.004 \\
(0.066)\end{array}$ & & & $\begin{array}{l}-0.074 \\
(0.190)\end{array}$ \\
\hline \multicolumn{2}{|c|}{ college or higher } & & $\begin{array}{l}-0.009 \\
(0.038)\end{array}$ & & & $\begin{array}{c}-0.135^{*} \\
(0.073)\end{array}$ & & & $\begin{array}{l}-0.110 \\
(0.077)\end{array}$ & & & $\begin{array}{l}-0.221 \\
(0.210)\end{array}$ \\
\hline \multicolumn{2}{|c|}{ catholic, non-observant } & & $\begin{array}{c}0.032 \\
(0.040)\end{array}$ & & & $\begin{array}{l}-0.025 \\
(0.081)\end{array}$ & & & $\begin{array}{l}-0.019 \\
(0.086)\end{array}$ & & & $\begin{array}{c}0.045 \\
(0.250)\end{array}$ \\
\hline \multicolumn{2}{|c|}{ catholic, observant } & & $\begin{array}{l}-0.027 \\
(0.041)\end{array}$ & & & $\begin{array}{l}-0.035 \\
(0.087)\end{array}$ & & & $\begin{array}{l}-0.059 \\
(0.091)\end{array}$ & & & $\begin{array}{c}0.090 \\
(0.260)\end{array}$ \\
\hline constant & $\begin{array}{c}0.0459 * * \\
(0.020)\end{array}$ & $\begin{array}{c}0.0653^{* *} \\
(0.029)\end{array}$ & $\begin{array}{c}0.0885^{*} \\
(0.049)\end{array}$ & $\begin{array}{c}0.056 \\
(0.039)\end{array}$ & $\begin{array}{c}0.074 \\
(0.059)\end{array}$ & $\begin{array}{c}0.152 \\
(0.110)\end{array}$ & $\begin{array}{c}0.0794 * * \\
(0.039)\end{array}$ & $\begin{array}{c}0.059 \\
(0.065)\end{array}$ & $\begin{array}{c}0.119 \\
(0.110)\end{array}$ & $\begin{array}{c}0.115 \\
(0.079)\end{array}$ & $\begin{array}{c}0.209 * \\
(0.110)\end{array}$ & $\begin{array}{c}0.305 \\
(0.320)\end{array}$ \\
\hline Observations & 252 & 248 & 245 & 203 & 202 & 198 & 156 & 155 & 155 & 47 & 47 & 43 \\
\hline R-Squared & 0.01 & 0.01 & 0.05 & 0.03 & 0.04 & 0.07 & 0.01 & 0.01 & 0.04 & 0.07 & 0.13 & 0.20 \\
\hline
\end{tabular}

Table 3: Robustness to regression analysis. The Table reports parameter estimates from linear probability regressions. The omitted categories are: age 18-39, donor since less than 2 years, education less than high school, religion atheist/agnostic. Standard errors are in parentheses. * denotes significance at 10 percent, ${ }^{* *}$ at 5 percent, and ${ }^{* * *}$ at 1 percent level. 


\begin{tabular}{|c|c|c|c|c|c|c|c|c|c|}
\hline \multirow[t]{2}{*}{ treatment } & \multirow[t]{2}{*}{$\begin{array}{l}\text { response to the } \\
\text { treatment question }\end{array}$} & \multicolumn{2}{|c|}{$\begin{array}{l}\text { donating makes me } \\
\text { feel a better person }\end{array}$} & \multicolumn{2}{|c|}{$\begin{array}{c}\text { paying donors } \\
\text { would help } \\
\text { stimulate donations }\end{array}$} & \multicolumn{2}{|c|}{$\begin{array}{l}\text { donors should have } \\
\text { priority in emergencies }\end{array}$} & \multicolumn{2}{|c|}{$\begin{array}{l}\text { donors' names } \\
\text { should be } \\
\text { made public }\end{array}$} \\
\hline & & mean & median & mean & median & mean & median & mean & median \\
\hline \multirow{4}{*}{ voucher } & $\begin{array}{c}\text { would donate } \\
\text { just as often or more }\end{array}$ & 4.06 & 4.00 & 2.72 & 3.00 & 2.51 & 3.00 & 2.49 & 3.00 \\
\hline & $\begin{array}{l}\text { would stop donating } \\
\text { or donate less }\end{array}$ & 3.88 & 5.00 & 1.80 & 1.00 & 2.63 & 2.50 & 1.86 & 1.00 \\
\hline & & \multicolumn{2}{|c|}{ WMW test, $\mathrm{p}=0.856$} & \multicolumn{2}{|c|}{ WMW test, $\mathrm{p}=0.115$} & \multicolumn{2}{|c|}{ WMW test, $\mathrm{p}=0.882$} & \multicolumn{2}{|c|}{ WMW test, $\mathrm{p}=0.147$} \\
\hline & & mean & median & mean & median & mean & median & mean & median \\
\hline \multirow{3}{*}{ cash } & $\begin{array}{c}\text { would donate } \\
\text { just as often or more }\end{array}$ & 4.15 & 4.00 & 2.60 & 3.00 & 2.50 & 2.50 & 2.50 & 3.00 \\
\hline & $\begin{array}{l}\text { would stop donating } \\
\text { or donate less }\end{array}$ & 4.26 & 5.00 & 1.62 & 1.00 & 2.20 & 1.00 & 1.84 & 1.00 \\
\hline & & \multicolumn{2}{|c|}{ WMW test, $\mathrm{p}=0.163$} & \multicolumn{2}{|c|}{ WMW test, $\mathrm{p}=0.000$} & \multicolumn{2}{|c|}{ WMW test, $\mathrm{p}=0.287$} & \multicolumn{2}{|c|}{ WMW test, $\mathrm{p}=0.017$} \\
\hline
\end{tabular}

Table 4: Questions on attitudes towards donations and rewards. The Table reports average and median responses to a series of questions, based on whether an individual was assigned to the "voucher" or the "cash" treatment and whether he/she responded that he/she would reduce his/her donations or stop donating in response to the 10-euro cash/voucher. Reported also is the p-value of the Wilcoxon-Mann-Whitney (WMW) test, a non-parametric test of the difference between the distributions of the responses to the various questions, by whether a donor responded that he/she would reduce donations or stop. 